\title{
The Relationship between Income Smoothing and Income Tax and Profitability Ratios in Iran Stock Market
}

\author{
Dr. Parviz Saeidi \\ Department of management,Aliabad katoul Branch \\ Islamic Azad University, Aliabad katoul, Iran \\ E-mail: dr.psaeidi@yahoo.com
}

Received: December 6, 2011 Accepted: January 8, 2012 Published: June 1, 2012

doi:10.5296/ajfa.v4i1.790 URL: http://dx.doi.org/10.5296/ajfa.v4i1.790

\begin{abstract}
The main goal of this study is to consider the relationship between income smoothing and tax income and profitability ratio, i.e. return on assets (ROA) and return on equity (ROE).Using the financial information of accepted companies in Iran stock exchange, the current researcher first made an attempt to distinguish between income smoother companies and non-income smoother companies based on Eckel index. After required modifications, a statistical population of 168 companies accepted in Iran stock exchange was obtained and their financial information was examined during 2001 to 20o7. Independent variables included tax income and profitability ratio (ROA and ROE) and dependent variables was income smoothing variable. The findings illustrated the fact that a significant relationship exists between income smoothing and tax income and profitability ratio.
\end{abstract}

Keywords: Income smoothing, Tax income, Profitability ratio, Return On Assets (ROA), Return on Equity (ROE) 


\section{Introduction}

Increasingly development of economical activities and their intricacies and also attending to accurate accounting information and financial statements have created modern analytical and managerial approaches in accounting.

Financial statements are the means by which managers are seeking to see the results of their control over the resources for which they are responsible. The mentioned statements are to convey such information as the financial position, performance and cash flows of a firm. As a firm's accounting records are not open to stockholders, they mostly rely on such financial statements in their judgments and decisions. For this reason, managers tend to report favorable accounting statistics in their financial statements. Manipulating accounting statistics may mislead the users of financial statements in their decisions. Bernea, Ronen and Sadan (1976) consider income smoothing as one of the common approaches of creative accounting in which fluctuations are deliberately manipulated and adjusted about some levels of earnings that is normal for the firm. Hepworth (1953) finds smoothing as a reasonable and wise action by which managers smooth their income by using specific means. Gordon, Horwitz and Meyers (1966) started off studies on the association between the accounting method of investment tax credits (income smoothing instrument) and the growth rates of earnings per share and the returns on the stockholders' equity (income smoothing objectives). They concluded that there is noteworthy relationship between them, which shows income smoothing practices are present. Archibald (1967) and cushing (1969) worked on depreciation methods and accounting changes respectively. Dascher and Malcom (1970), Barnea, Ronen and Sadan (1975) by investigating extraordinary items reported income smoothing behavior among selected companies. Beidleman (1973) stated that companies use incentive compensation, pension and retirement expenses, research and development costs, sales and advertising expenses to smooth their income.

Some researchers in their studies on smoothing income claim that those companies with stable growth rate mislead market. These researchers have come up whit this idea based on unusual observations and also estimating risk methods. They believe that a relationship exists between income variance and risk. Therefore, if there is evidence of the variance of income, it will affect the stockholder's interpretation of the firm's risk.

In Iran, tax system plays a key role in financial reports of firms and tax regulations is the main factor in selecting the type of accounting policies and methods. Firms tend to smooth their income so as to minimize tax effects during the time. Since more income leads to pay more tax and indeed results in going out liquidity, Iranian firms smooth income in order to minimize going out liquidity particularly in the cases that firms owe considerable tax debts.

In this paper, in order to measure profitability ratio, two key financial business ratios to measure a company's efficiency are Return on Assets (ROA) and Return on Equity (ROE) (Saeidi, 2007, p.114). The former shows the after tax earnings of assets and is an indicator of how profitable a company is. Return on assets ratio is the key indicator of the profitability of a company. This ratio is calculated by using the following formula: Net Profit after Taxes /Total Assets. The latter measures the return on the money the investors have put into the 
company. Return on Equity ratio is the key indicator of the management performance. This is calculated by: Net Income/Stockholder's Equity

\section{Literature Review}

Income smoothing has been a topic of interest among many researchers for decades especially after 1970. Eckel (1981) revisited the previous researches on income smoothing and suggested an alternative conceptual framework to discern income smoothing manner. He criticized most of the researches for using one accounting variable to determine income smoothing. He suggested that firms with a smooth income use the joint effect of accounting variables so as to minimize income variables to the least. He concluded that just three percent of selected sample were carrying out artificial smoothing. Although only using sale and income variables in his test, he thought that income arises from the difference between sale and stable and unstable expenses are caused by different variables.

Ryahi Bolouki and Pikvar (2002) by dividing the companies into two sections including central and peripheral industries tested the hypothesis to demonstrate that central companies are of less smoothing ratio than peripheral companies. They concluded that peripheral companies report more smoothing behavior than central companies do. Moses (1987) demonstrated that accounting changes are considered as income smoothing devices. He indicated that accounting changes can be used to minimize income fluctuation instead of maximizing or minimizing reported income. His research was bases on two tests. The first one examined those companies with a smooth income and the other one investigated the effects of motivational factors toward income smoothing. He found smoothing behavior as subject to management motivations. Hunt et al. (2000) claimed that income smoothing enhances synchronic price-earnings relations for each they thought that income smoothing provide better information on earnings.

\section{Research Methodology}

This research is basically of casual and applied research types and employed the coefficient of variation method developed by Eckel (1981) to determine the presence of income smoothing. In this method, the coefficient of variations is used to measure the variability of sales and income. This method has been used by many previous studies in determining the presence of income smoothing like Albrecht and Richardson (1990). The company is artificial smoothing if $\frac{C V \Delta I}{C V \Delta S}<1$.

$$
\begin{aligned}
\mathrm{CV} \Delta \mathrm{I} & =\frac{\sqrt{\sum\left(\Delta I_{\mathrm{i}}-\Delta \bar{I}\right)^{2}} / n-1}{\Delta \bar{I}} \\
\mathrm{CV} \Delta S & =\frac{\sqrt{\sum\left(\Delta S_{\mathrm{i}}-\Delta \bar{S}\right)^{2}} / n-1}{\Delta \bar{S}}
\end{aligned}
$$


$\Delta I=$ Income change

$\Delta S=$ Selling change

$C V=$ Coefficient of variation

$\bar{S}=$ Selling average

$\bar{I}=$ Income average

\section{Statistical Population}

In order to analyze income soothing practices in the current study, numbers of accepted companies in Tehran stock exchange including168 companies were selected according to the following conditions:

1. The selected companies must have the whole 10 -year period and have fiscal- year end of $12 / 29$.

2. Companies must be continuously selling their shares in Tehran stock exchange.

3. Companies must not be of brokerage companies and their financial information is available within the whole 10 -year period.

4. Companies must be profitable.

\section{Findings}

\subsection{The First Hypothesis Testing:}

H0: There is NO relationship between the income tax of accepted companies in Tehran stock exchange and income smoothing.

H1: There is relationship between the income tax of accepted companies in Tehran stock exchange and income smoothing.

For testing the firs hypothesis, Logit model developed type of linear regression was used. The results are illustrated in the following table.

Table 1. The relationship between tax income and income smoothing

\begin{tabular}{|c|c|c|c|c|}
\hline \multicolumn{5}{|c|}{ Likelihood Ratio Tests } \\
\hline \multirow[b]{2}{*}{ Effect } & \multirow{2}{*}{\begin{tabular}{|l|} 
Model Fitting Criteria \\
-2 Log Likelihood of Reduced Model
\end{tabular}} & \multicolumn{3}{|c|}{ Likelihood Ratio Tests } \\
\hline & & Chi-Square & Df & Sig. \\
\hline Intercept & $5.545^{\mathrm{a}}$ & .000 & 0 & . \\
\hline $\operatorname{tax}$ & 228.733 & 223.187 & 162 & .001 \\
\hline
\end{tabular}

According to Logistic correlation test, the amount of sig obtained is $0 / 001$ with the confidence level of 0/95 that rejected H0. In other words, there is significant relationship 
between income smoothing and tax income of selected companies. The findings obtained from $\mathrm{HO}$ indicated that a positive relationship existed between tax income and income smoothing. Considering the table 1 , coefficient of sig is $0 / 001$ that rejected $\mathrm{H} 0$ and confirmed a significant relationship between tax income and income smoothing. Taking this fact into account that an increase in income increases tax and a reduction in liquidity, Iranian companies tend to smooth their income so as to decrease a reduction in liquidity particularly when they are suffering from large tax debts.

\subsection{The Second Hypothesis Testing}

H0: There is NO reasonable relationship between return on investment (ROI) of accepted companies in Tehran stock exchange and income smoothing.

H1: There is reasonable relationship between return on investment (ROI) of accepted companies in Tehran stock exchange and income smoothing.

Table 2. The relationship between ROI and income smoothing

\begin{tabular}{|l|l|l|l|l|}
\hline \multicolumn{4}{|l|}{ Likelihood Ratio Tests } \\
\hline \multirow{3}{*}{ Effect } & Model Fitting Criteria & \multicolumn{4}{l|}{ Likelihood Ratio Tests } \\
\cline { 2 - 6 } & -2 Log Likelihood of Reduced Model & Chi-Square & df & Sig. \\
\hline Intercept & $.000^{\mathrm{a}}$ & .000 & 0 &. \\
\hline ROI & 234.278 & 234.278 & 167 & .000 \\
\hline
\end{tabular}

According to Logistic correlation test, the amount of sig obtained is $0 / 0$ with the confidence level of 0/95 that rejected $\mathrm{H0}$ and accepted H1. In other words, there is a significant relationship between ROI and income smoothing.

\subsection{The Third Hypothesis Testing}

H0: There is NO reasonable relationship between return on equity (ROE) of accepted companies in Tehran stock exchange and income smoothing.

H1: There is reasonable relationship between return on equity (ROE) of accepted companies in Tehran stock exchange and income smoothing.

Table 3. The relationship between ROE and income smoothing Likelihood Ratio Tests

\begin{tabular}{|l|l|l|l|l|}
\hline \multirow{2}{*}{ Effect } & \multicolumn{2}{|l|}{ Model Fitting Criteria } & \multicolumn{3}{|l|}{ Likelihood Ratio Tests } \\
\cline { 2 - 6 } & -2 Log Likelihood of Reduced Model & Chi-Square & df & Sig. \\
\hline Intercept & $.000^{\text {a }}$ & .000 & 0 &. \\
\hline ROE & 154.421 & 154.421 & 122 & .025 \\
\hline
\end{tabular}

According to Logistic correlation test, the amount of sig obtained is $0 / 025$ with the confidence level of 0/95 that rejected H0 and accepted H1. In other words, there is a significant relationship between ROE and income smoothing. 


\section{Conclusion}

The hypotheses testing indicated that a significant relationship existed between tax income and income smoothing, and they also demonstrated that the tax income of income-smoothing companies is less than that of non-income smoothing companies. Finally a significant relationship existed between profitability ratio and income smoothing.

\section{Acknowledgment}

The author wishes to thank Mr. Ramin Rezaei M.A. who assisted in the proof-reading of the manuscript

\section{References}

Albecht, W. D., \& Richardson, F. M. (1990). Income smoothing by economy sector. Journal of business finance and accounting, 17 (5), 713-730. http://dx.doi.org/10.1111/j.1468-5957.1990.tb00569.x

Ashari, N., Koh, H., Tan, S., \& Wong, W. (1994). Factors affecting income smoothing among listed companies in Singapore. Accounting and Business Research, 24 (96), 291-301.

Bamea, A., J., Ronen, \& S., Sadan. (1975). The implementation of accounting objectives-An application to extraordinary items. The Accounting Review, January, pp.55-68.

Barnea, A., J. Ronen, \& S. Sadan. (1976). Classificatory smoothing of income with extraordinary items. The Accounting Review, January, 56 (1), 110-112.

Beidleman, C.R. (1973). Income smoothing: The role of Management. The Accounting Review, October, 48 (4), 653-667.

Carlson, S. J., \& Bathala, C. T. (1997). Ownership differences and firms income smoothing behavior. Journal of business finance and accounting, March, Vol. 24, pp. 179-182.

Eckel, N. (1981). The income smoothing Hypothesis Revisited Abacus, 17 (1) 28-40.

Hepworth, S.R. (1953). Smoothing periodic income. Accounting Review, 28 (1), 32-39.

Jones, J. (1991). Earnings management during import relief investigations. Journal of Accounting Research, 29. pp. 93-228. http://dx.doi.org/10.2307/2491047

Kamarudin, K.A., Bin, K. W., \& Kamil, K. (1999). Market perception of income smoothing practices: Malaysian evidence. University of technology Malaysia.

Moses, A.D. (1987). Income smoothing and incentives: Empirical tests using accounting changes. The Accounting Review, April, pp. 358-377.

Ryahi, B., A., \& Pikvar, A. (2002). Accounting theories. Cultural Research Office publication, Tehran, pp. 508-514.

Saeidi, P. (2007). Financial Management, Vol. 1, Tehran, Negahe Danesh publication. 